\title{
Overcoming chemoresistance in pancreatic cancer cells: role of the bitter taste receptor T2R 10
}

\author{
Louisa Stern ${ }^{1}$, Nathalia Giese ${ }^{1}$, Thilo Hackert ${ }^{1}$, Oliver Strobel ${ }^{1}$, Peter Schirmacher ${ }^{2}$, Klaus Felix ${ }^{1}$, Matthias \\ M. Gaida ${ }^{\square}$ \\ 1. Department of General, Visceral and Transplantation Surgery, University Hospital Heidelberg, Heidelberg, Germany \\ 2. Institute of Pathology, University Hospital Heidelberg, Heidelberg, Germany \\ $\square$ Corresponding author: Matthias M. Gaida, M.D., Institute of Pathology, University Hospital Heidelberg, Im Neuenheimer Feld 224, D-69120 Heidelberg, \\ Germany. Tel: +49-6221 56-4161; Fax: +49 622156 -5251; email: Matthias.Gaida@med.uni-heidelberg.de \\ (c) Ivyspring International Publisher. This is an open access article distributed under the terms of the Creative Commons Attribution (CC BY-NC) license \\ (https://creativecommons.org/licenses/by-nc/4.0/). See http://ivyspring.com/terms for full terms and conditions.
}

Received: 2017.10.18; Accepted: 2017.11.26; Published: 2018.02.01

\begin{abstract}
Bitter taste receptors (T2Rs) are G-protein coupled transmembrane proteins initially identified in the gustatory system as sensors for the taste of bitter. Recent evidence on expression of these receptors outside gustatory tissues suggested alternative functions, and there is growing interest of their potential role in cancer biology. In this study, we report for the first time, expression and functionality of the bitter receptor family member T2R10 in both human pancreatic ductal adenocarcinoma (PDAC) tissue and PDAC derived cell lines. Caffeine, a known ligand for T2R10, rendered the tumor cells more susceptible to two standard chemotherapeutics, Gemcitabine and 5-Fluoruracil. Knocking down T2R 10 in the cell line BxPC-3 reduced the caffeine-induced effect. As possible underlying mechanism, we found that caffeine via triggering T2R10 inhibited Akt phosphorylation and subsequently downregulated expression of ABCG2, the so-called multi-drug resistance protein that participates in rendering cells resistant to a variety of chemotherapeutics. In conclusion, T2R 10 is expressed in pancreatic cancer and it downmodulates the chemoresistance of the tumor cells.
\end{abstract}

Key words: Pancreatic cancer, bitter receptors, chemoresistance, caffeine

\section{Introduction}

Pancreatic ductal adenocarcinoma (PDAC) is the fourth leading cause of cancer deaths with a 5-year survival rate of approximately 7\% [1]. Due to late occurrence of symptoms and thus often progressed disease, only a minor percentage of PDAC patients is suitable for potential curative surgery [2]. Therefore, chemotherapy often remains the last treatment option [2]. However, its effectiveness is limited because pancreatic cancer exhibits numerous mechanisms of resistance towards a wide variety of drugs [3, 4]. Thus, understanding resistance on a molecular basis is imperative for the development of novel therapeutic targets to restore drug efficacy and to overcome chemoresistance. A plethora of synthetic and natural compounds has been tested so far, often in combination with conventional chemotherapy, to improve chemotherapeutic regimen for malignancies, including PDAC [5-9]. In this context, bitter tasting substances and the family of their corresponding receptors came into focus.

Bitter taste receptors (T2R) are classical G-protein coupled seven transmembrane-domain receptors that respond to ligation with various bitter compounds of foods [10-13], such as sinigrin in vegetables [14], caffeine and epigallocatechin-3gallate in green tea [15], of drugs such as erythromycin [12], or metabolites of the microbiome [16]. In humans, the family of T2R is composed of 25 functional receptors [11]. Based on initial description of these receptors in the oral cavity, it was originally assumed that they mediate exclusively the perception of bitter taste. However, recent studies described the 
presence of these receptors in non-gustatory cells, including airway epithelia [17], breast epithelia [18], gastro-intestinal cells [19], placental [20], brain [21], or myeloid cells [16], suggesting functions apart from sensing bitter. Sensing bacterial-derived products and thus participating in the local host response has been suggested for receptors expressed on epithelial cells $[17,22]$ or myeloid cells [16]. Recent reports described a functional role of T2R10 as bronchodilator and vasomodulator in smooth muscle cells, because activation by bitter agonists causes changes in $\mathrm{Ca}^{2+}$ oscillations that resulted in relaxation of smooth muscle cells [23-26]. Moreover, a potential role in cancer biology has been shown recently for the family member T2R38 in pancreatic cancer; its stimulation upregulates the multi-drug-resistance-protein ABCB1, a major player in the induction of chemoresistance [27]. On the other hand, bitter compounds can also display anticancer or chemotherapy enhancing activities, whereby the exact mechanisms are often still unknown [28-32]. Most of the bitter receptors are promiscuous, and - by not yet well-understood mechanisms - can be triggered by different chemically not related substances. One of those receptors is T2R10, which reacts with caffeine, coumarin, erythromycin, and haloperidol [12], but its role beyond sensing bitter is unexplored. A cancer-related expression of T2R10 has been shown in breast cancer cell lines, although a function has not been described yet [18].

The aim of the present study was to evaluate the expression of T2R10 receptor in PDAC tissue and in tumor derived cell lines (AsPC-1, BxPC-3, Capan-1, COLO-357, MiaPaCa-2, SU.86.86, PANC-1, and T3M4), and to investigate a functional role of this receptor in the context of chemoresistance.

\section{Materials and Methods}

\section{Chemicals, Reagents, and Antibodies}

Caffeine (Sigma Aldrich, St. Louis, MO, USA) was dissolved in distilled water, Gemcitabine (Eli Lilly \& Co., Indianapolis, IN, USA) in phosphate buffered saline (PBS; Sigma Aldrich), and 5-Fluorouracil (5-FU; Sigma Aldrich) in Dimethylsulfoxide (DMSO; Sigma Aldrich). For Western blot analysis the following antibodies were used: anti-ABCG2 (EPR2099, abcam); anti-Phospho-Akt Ser473 (D9E, Cell Signaling, Cambridge, UK), anti-pan-Akt (C67E7, Cell Signaling); anti-GAPDH (14C10, Cell signaling); anti-T2R10 (orb 164582; Biorbyt, Cambridge, UK); anti-tubulin (sc-58886, Santa Cruz); goat anti-rabbit IgG-horse radish peroxidase (HRP; Santa Cruz) as secondary antibody. For flow cytometry, a Fc Blocking Reagent (human,
Miltenyi Biotec, Bergisch-Gladbach, Germany) was used; anti-T2R10 (ab138285, abcam, Cambridge, UK), a rabbit polyclonal isotype control (abcam), and anti-rabbit-IgG conjugated with phycoerythrin (PE) (Jackson Immunoresearch, West Grove, PA, USA).

\section{Cell Culture}

The pancreatic cancer cells AsPC-1, BxPC-3, Capan-1, COLO-357, MiaPaCa-2, SU.86.86, PANC-1, and T3M4 were obtained from ATCC (Rockville, MD, USA). All cells were cultured in RPMI 1640 supplemented with $10 \%$ calf serum and $1 \%$ penicillin-streptomycin all from Life Technologies (Darmstadt, Germany). Cells were maintained in a humidified atmosphere with $5 \% \quad \mathrm{CO}_{2}$ at $37^{\circ} \mathrm{C}$. Accutase (Life Technologies) was used for detaching cells.

\section{Patients and Biopsies}

Pancreatic tissue samples were obtained from the Pancobank of the European Pancreas Center, Department of Surgery, University Hospital Heidelberg or the tissue bank of the National Center for Tumor Diseases (NCT, Heidelberg, Germany) in accordance with the regulations of the tissue bank. The histological examination of formalin fixed, paraffin embedded and H\&E stained pancreatic tissue sections was performed at the Pathology Department University of Heidelberg. The study was approved by the ethics committee of the University of Heidelberg (approval votes no. 301/2001, 159/2002, 206/2005), and a written informed consent was obtained from all patients. Patient demographics and clinical data are summarized in table 1.

\section{Tissue staining}

After deparaffinization and rehydration of the tissue in xylene and graded alcohols, an anti-human T2R10 antibody (Thermo Scientific, 1:400, retrieval condition: citrate buffer, $\mathrm{pH}$ 6.0) was incubated for 1 hour at room temperature. As secondary antibody the DCS Detection Line Super Vision Red2 system (Innovative Diagnostik-Systeme, Hamburg, Germany) was used, followed by the color reaction with liquid permanent red (Zytomed, Berlin, Germany) and counter stain with hematoxylin. Presence of T2R10 was evaluated using an established scoring system in which the sum of the staining intensity (0: absent; 1 : weak; 2 : moderate; 3 strong) and distribution (0: absent; 1: $0-1 \% ; 2:>1-10 \%$; 3 : > $10-33 \%$; 4: > $33-66 \%$; 5: > $66-100 \%$ ) was calculated (Allred [33]). The intratumor inflammation was determined on whole tumor sections by evaluating the accumulation of inflammatory cells (lymphocytes, plasma cells, macrophages). Severity was determined as absent (score 0 ), mild (score 1), moderate (score 2), 
and severe (score 3). Activity of inflammation was judged by the density of neutrophils, and scored as absent (score 0), mild (score 1), and moderate to severe (score 2), using an established scoring system for pancreatic cancer [34]. Infiltrated $T$ cells were identified by expression of CD3 (antibody obtained from Thermo Scientific, Darmstadt, Germany).

Table 1. Patients data

\begin{tabular}{|c|c|c|}
\hline diagnosis & pancreatic ductal adenocarcinoma & $\begin{array}{l}\text { number of } \\
\text { patients (62) }\end{array}$ \\
\hline gender (female : male) & $30: 32$ & \\
\hline age (years) & 39-83 (mean: 65.5; median: 65.5) & \\
\hline \multirow{3}{*}{$\begin{array}{l}\text { localization of the } \\
\text { tumor }\end{array}$} & head & 47 \\
\hline & body & 14 \\
\hline & tail & 1 \\
\hline \multirow[t]{3}{*}{ tumor size *pT } & pT1 (smaller $2 \mathrm{~cm}$ ): & 9 \\
\hline & pT2 (between 2 and $4 \mathrm{~cm}$ ): & 31 \\
\hline & pT3 (larger than $4 \mathrm{~cm}$ ): & 22 \\
\hline \multirow[t]{3}{*}{$\begin{array}{l}\text { lymph node } \\
\text { metastases }{ }^{*} \mathrm{pN}\end{array}$} & $\begin{array}{l}\text { pN0: no regional lymph node } \\
\text { metastases }\end{array}$ & 7 \\
\hline & $\begin{array}{l}\text { pN1: metastases in } 1 \text { to } 3 \text { regional } \\
\text { lymph nodes }\end{array}$ & 27 \\
\hline & $\begin{array}{l}\text { pN2: metastases in } 4 \text { or more } \\
\text { regional lymph nodes }\end{array}$ & 28 \\
\hline \multirow[t]{2}{*}{${ }^{*} \mathrm{pM}$} & pM0: no distant metastases & 54 \\
\hline & pM1: distant metastases & 8 \\
\hline \multirow{3}{*}{$\begin{array}{l}\text { histological grading } \\
\text { (growth pattern) }\end{array}$} & G1: well differentiated & 4 \\
\hline & G2: moderately differentiated & 39 \\
\hline & $\begin{array}{l}\text { G3: poorly differentiated } \\
\text { one patient excluded because of } \\
\text { neoadjuvant therapy }\end{array}$ & 18 \\
\hline \multirow{2}{*}{$\begin{array}{l}\text { neoadjuvant } \\
\text { chemotherapy }\end{array}$} & received & 1 \\
\hline & not received & 61 \\
\hline \multirow[t]{3}{*}{ resection margin } & $\begin{array}{l}\text { more than } 1 \mathrm{~mm} \text { from resection } \\
\text { margin }\end{array}$ & 10 \\
\hline & $\begin{array}{l}\text { less than } 1 \mathrm{~mm} \text { from resection } \\
\text { margin }\end{array}$ & 46 \\
\hline & no data & 6 \\
\hline
\end{tabular}

*Pathological evaluation according to the guidelines of the Union for International Cancer Control 2017

\section{Gene expression Analysis}

The mRNA data of T2R10 expression in PDAC tumors $(n=84)$ was obtained from the database of the Heidelberg Institute of Personalized Oncology (HiPO) biobank. Tumor samples with reads per kilobase per million mapped reads $(\mathrm{rpkm}) \geq 1$ for T2R10 were defined as T2R10 positive [35]. Follow-up data were available in 46 cases. Kaplan-Meier analysis was used to determine survival and differences between patients with T2R10 negative $(<1.0 \mathrm{rpkm})(\mathrm{n}=8)$ and T2R10 positive PDAC tumors $(\geq 1.0 \mathrm{rpkm})(\mathrm{n}=38)$ were calculated using Rank correlation.

\section{Reverse transcription polymerase chain reaction (RT-PCR)}

Total RNA was isolated using Magna-Pure LC RNA Isolation Kit High Performance (Roche lifescience, Indianapolis, USA) according to the manufacturer's instructions. cDNA was then generated with the $1^{\text {st }}$ Strand cDNA Synthesis Kit from Roche Diagnostics and used as a template for polymerase chain reaction (PCR). The PCR was carried out in a $25 \mu \mathrm{l}$ reaction mixture containing 12.5 $\mu l$ Read Tag Mix Ready Use (Sigma Aldrich), $0.4 \mu \mathrm{M}$ Primer, $8 \mu \mathrm{l}$ nuclease-free water (Sigma Aldrich) and 2 $\mu l$ cDNA. T2R10-Primer sequences were as follows: forward GACTTGTAAACTGCATTGACTGTGCC, and reverse AAAGAGGCTTGCTTTAGCTTGCTG. For GAPDH (glycerin aldehyde-3-phosphate dehydrogenase) used as control the forward primer was GCCAAAAGGGTCATCATCTC and reverse primer GTAGAGGCAGGGATGATGTTC. The PCR reaction consisted of 10 minutes initial denaturation at $94^{\circ} \mathrm{C}$ following for 50 cycles of 30 seconds denaturation $\left(94^{\circ} \mathrm{C}\right), 30$ seconds annealing $\left(60^{\circ} \mathrm{C}\right), 30$ seconds extension $\left(72^{\circ} \mathrm{C}\right)$ and a final extension for 2 minutes at $72^{\circ} \mathrm{C}$. Products were separated on a $1.5 \%$ agarose gel stained with ethidium bromide. Fusion-SL (Vilber, Eberhardzell, Germany) was used for capturing gel images under UV light. For control, reactions were performed using water instead the sample, or without master mix (polymerase, primer).

\section{Flow Cytometry}

For flow cytometry analyses $\sim 1 \times 10^{6}$ cells were harvested with Accutase (Life technologies, Darmstadt, Germany) and resuspended in $100 \mu \mathrm{l}$ flow cytometry buffer (FACS buffer: PBS; 0.5\% FCS) followed by fixation in ice-cold Methanol $(80 \%)$ for 20 minutes at $4^{\circ} \mathrm{C}$. Then, cells were washed with flow cytometry buffer and permeabilized with PBS plus 1\% Tween 20 (Gerbu Biotechnik, Heidelberg, Germany) for 20 minutes at room temperature. After washing with FACS-buffer containing $0.1 \%$ Tween 20, cells were pre-incubated with $10 \mu \mathrm{l} \mathrm{Fc} \mathrm{Blocking} \mathrm{Reagent}$ (Becton and Dickinson, Heidelberg, Germany) for 15 minutes. Then the primary antibody against T2R10 (ab138285, abcam, Cambridge, UK) $(20 \mathrm{ng} / \mathrm{ml})$ and IgG isotype control $(20 \mathrm{ng} / \mathrm{ml})$ were incubated for 35 minutes, respectively. Cells were washed and incubated with a PE-labeled secondary antibody (5 $\mathrm{ng} / \mathrm{ml}$ ) for 20 minutes protected from light. Finally, cells were washed and resuspended in $300 \mu \mathrm{l}$ buffer. All incubation steps were performed at room temperature. BD FACS Canto 2 was used for detection. Results were analyzed with FlowJo 10.0.8 software (Tree Star, Ashland, OR, USA). The mean fluorescence intensity (MFI) was used to show expression. In the knock down experiments, the MFI of cells treated with siRNA negative control was defined as $100 \%$. Knockdown efficacy was expressed as percentage decrease of MFI. 


\section{Transfection}

siRNA Select against T2R10 and siRNA negative control Select 1 were purchased from Invitrogen (Carlsbad, CA, USA). Reverse transfection with $10 \mathrm{nM}$ siRNA in the presence of Hiperfect (Qiagen, Hilden, Germany) was performed according to the manufacturer's instructions. 200,000 cells were seeded and cultured for 48 hours before performing a retransfection. Another 48 hours later siRNA knock down efficacy of T2R10 was assessed by flow cytometry.

\section{Drug Treatment}

For Western blot (WB) analysis and crystal violet assays 200,000 cells in $2 \mathrm{ml}$ medium were seeded in 6-well plates and for MTS assays 5,000 cells with 100 $\mu \mathrm{l}$ were seeded in 96-well plates. Cells were cultured for 96 hours and treated according to the protocol shown in supplementary Fig. 1A. Caffeine (dotted lines) was added to the medium at $12,24,48,72$, and 84 hours after seeding, each time at a concentration of $100 \mu \mathrm{M}$ or $200 \mu \mathrm{M}$, respectively. These concentrations were not toxic for the tumor cells. A single dose of chemotherapeutic drug (solid line) was administered 24 hours after seeding. BxPC-3 cells were treated with either $5 \mathrm{nM}$ Gemcitabine or $500 \mathrm{nM}$ 5-FU and PANC-1 cells with $500 \mathrm{nM}$ Gemcitabine or $2 \mu \mathrm{M}$ 5-FU. Sensitivity to drugs (chemoresponse assays) and cell harvesting for further protein analyses were performed $72 \mathrm{~h}$ post drug exposure. For T2R10 knockdown experiments, cells were reversely transfected with siRNA, with treatment starting point delayed by 12 hours. These cells were cultured for a total of 108 hours as shown in supplementary Fig. 1B. T2R10 knockdown cells used for protein lysates were retransfected with siRNA 48 hours after seeding as shown in supplementary Fig 1C.

B
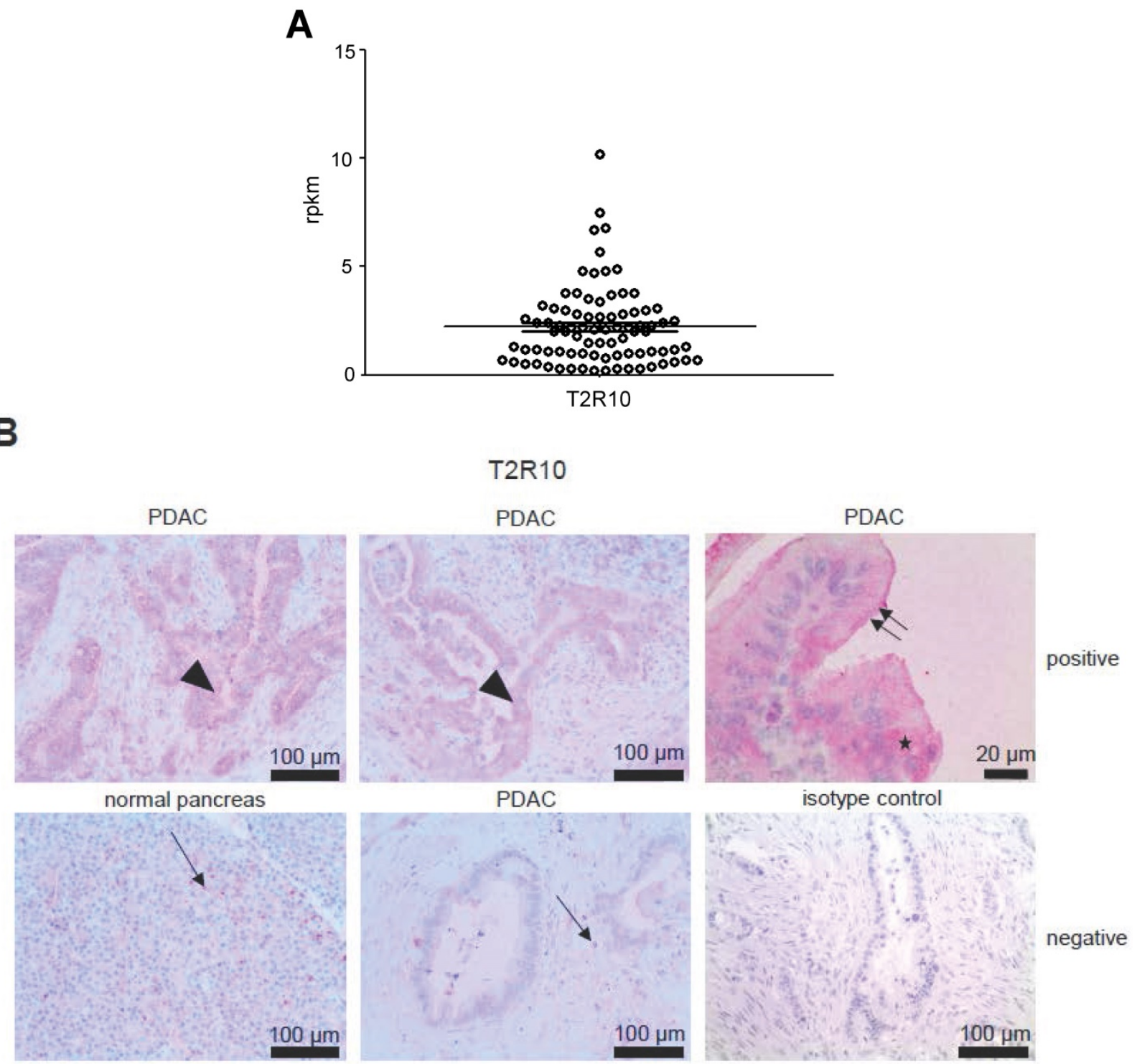
C

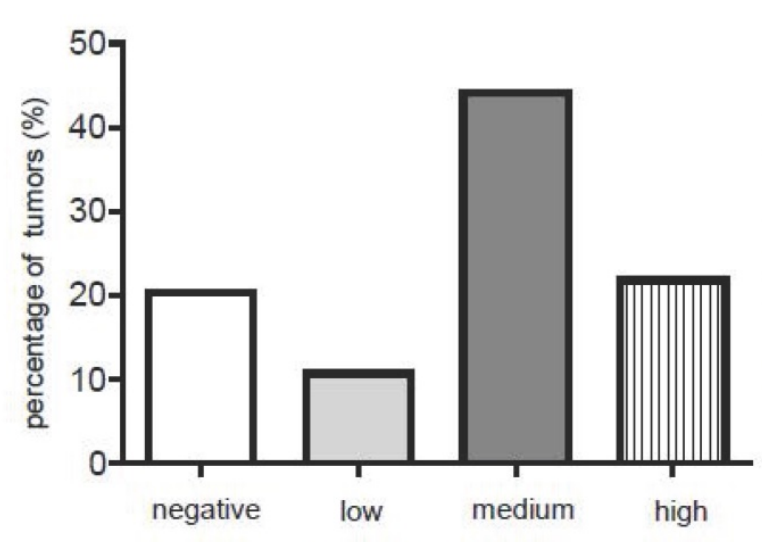

T2R10 expression

E
D

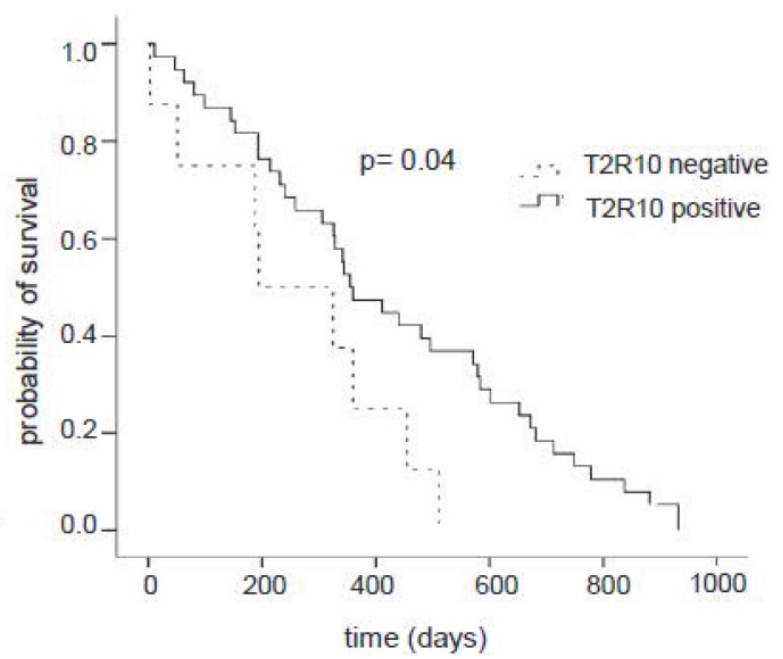

CD3

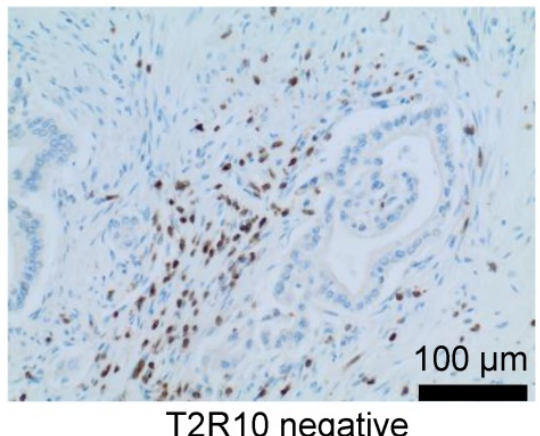

T2R10 negative

F

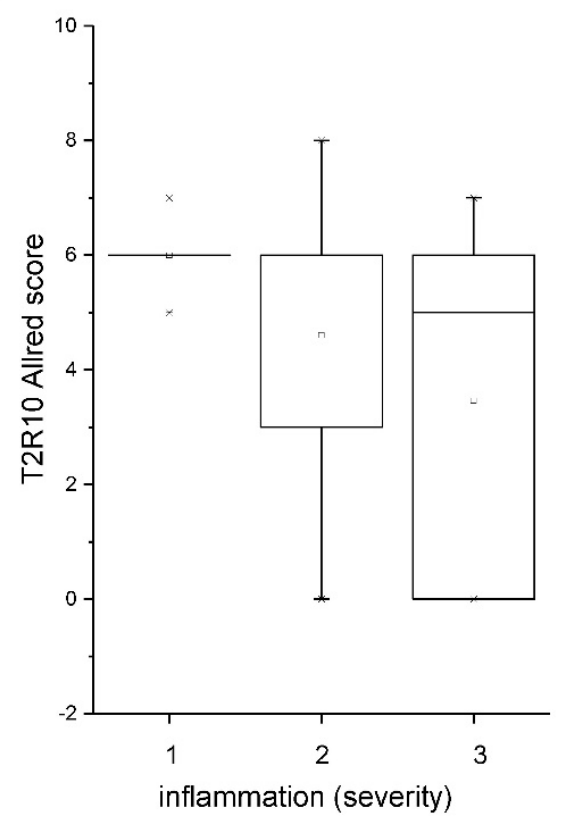

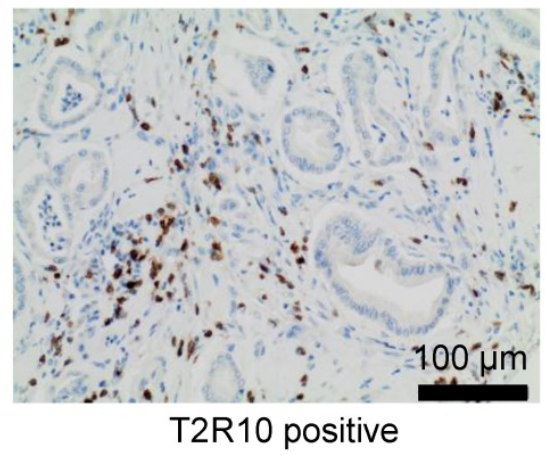

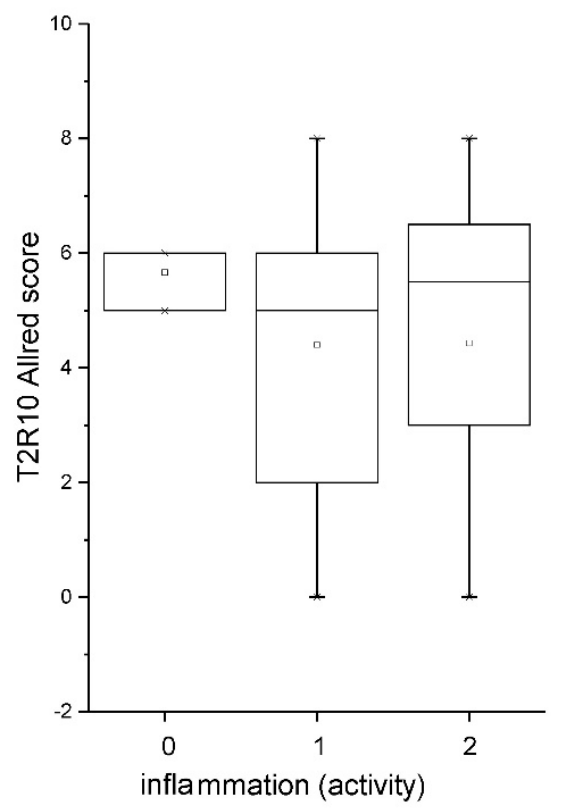

Figure 1: T2R 10 expression in PDAC tissue. A RNA Sequencing data showing T2R10 transcripts in PDAC tumor samples of 84 patients (Data are presented as quantified transcript levels in reads per kilobase of exon model per million mapped reads (rpkm). B Representative tissue specimen of PDAC tumors from three patients (upper panel) and of normal pancreas. T2R10 was detected in tumor cells (arrowheads) and immune cells (arrows). High magnification (upper panel, right) shows expression of T2R10 on the cell membrane and in the cytoplasm (asterisk). C Tumor samples ( $=62$ ) were categorized according to their T2R10 expression using an immunoreactivity score; negative= score 0 , low= score $2-3$, medium= score 4-6, high= score 7-8. D Kaplan-Meier survival analysis of PDAC patients with T2R 10 negative $(n=8)$ and T2R 10 positive PDAC tumors $(n=38)$ E Infiltrated T cells, identified by expression of CD3 are shown; $\mathbf{F}$ Inflammation severity scores $(0-3)$ and activity scores (0-2) were related to T2R 10 expression, the latter quantified using Allred score. The groups did not differ from each other. 


\section{Chemoresponse assays}

Two ml medium containing 200,000 cells per well were seeded in 6-well plates and treated with either caffeine, Gemcitabine, 5-FU, or in combination according to the scheme presented above in supplementary Fig 1A. BxPC-3 cells were treated with $5 \mathrm{nM}$ Gemcitabine or $500 \mathrm{nM} 5-\mathrm{FU}$, and PANC-1 cells with $500 \mathrm{nM}$ Gemcitabine or $2 \mu \mathrm{M}$ 5-FU, respectively. Five applications of either $100 \mu \mathrm{M}$ or $200 \mu \mathrm{M}$ caffeine were added to the medium. On day 0 and day 3 , a crystal violet assay was performed. $1 \mathrm{ml}$ of $0.05 \%$ crystal violet in $20 \%$ ethanol was added to each well. Cells were stained for $20 \mathrm{~min}$ at room temperature. Crystal violet was rinsed using cold tap water and plates were dried overnight. The next day, $1 \mathrm{ml}$ of methanol per well was added to elute the stained crystals from the cells. Plates were placed on a horizontal shaker for $20 \mathrm{~min}$ and absorbance was measured at $\lambda=595 \mathrm{~nm}$. Untreated cells were used for normalization. The optical densities [36] were normalized to day 0 ( $0 \%$ growth) and day three $(100 \%$ growth).

To test for cytotoxicity, the $\mathrm{IC}_{50}$ was determined by 3-(4,5-dimethylthiazol-2-yl)-5-(3-carboxymethoxyphenyl)-2-(4-sulfophenyl)-2H-tetrazolium (MTS) cell viability assays. 5,000 cells were seeded in $100 \mu \mathrm{l}$ medium per 96-well. MTS measurements were performed on day 0 and day 3. $10 \mu \mathrm{l}$ of MTS CellTiter 96 Aqueous One Solution (Promega, Wisconsin, USA) was added to each well. After 2 hours incubation at $37^{\circ} \mathrm{C}$ absorbance was measured at $490 \mathrm{~nm}$ using Synergy HTX Multi-Mode-Reader (Biothek, Wörrstadt, Germany). For normalization optical density values [36] obtained on day 0 were defined as $0 \%$ growth. ODs of cells not treated with chemotherapy were measured on day 3 were defined as $100 \%$ growth. This was done separately for the control (PBS) and caffeine treatment group. To assess synergism, the combined drug intoxication (CDI) was calculated [37].

\section{Western Blot Analysis}

After the respective treatments (Supplementary Fig. 1A, 1C), cells were washed twice with PBS (Sigma Aldrich), transferred in RIPA lysis buffer (Santa Cruz) and sonicated (Bandelin Berlin, Germany) for 45 seconds on ice, to support cell lysis, DNA fragmentation and cell membrane disintegration. Protein concentration was measured using BCA Protein Assay Kit [38] according to the manufacturer's instructions. Samples were mixed with Sample Buffer and Reducing Agent (Invitrogen) and separated on a $4-12 \%$ Bis-Tris-Gel (Invitrogen). After blotting, the membranes were blocked in 5\% milk powder dissolved in Tris-buffered saline with $0.1 \%$ Tween 20 (TBST) for one hour at room temperature. Primary antibodies were incubated overnight at $4^{\circ} \mathrm{C}$. The next day membranes were washed three times with TBST and once with TBS, for 10 minutes and subsequently incubated with secondary antibodies conjugated to horseradish peroxidase for one hour at $4^{\circ} \mathrm{C}$. After washing three times, the horseradish peroxidase reaction was visualized with ECL solution (SuperSignal West Dura Extended Duration Substrate, Thermo Fischer Scientific). WB images were captured using Fusion-SL (Vilber). Band intensities were quantified with Image J Software (NIH, Bethesda, USA). They were normalized to GAPDH in the case of ABCG2 and to pan-Akt for phosphorylated-Akt. Protein levels in the control group were defined as $100 \%$. For each experimental condition, at least three blots were done.

\section{Statistical Analysis}

$\mathrm{IC}_{50}$ doses were calculated using Graph Pad Prism Software 5.0 (GraphPad Software Inc., La Jolla, CA, USA). Statistical significance of data obtained from proliferation assays was tested by running extra-sum-of-squares $\mathrm{F}$ tests and One-way-Anova followed by Dunnett post-hoc- tests. Statistical analysis of expression data was performed with the appropriate tests for the clinical correlations (Mann-Whitney-U) and Log-Rank-survival test.

\section{Results}

\section{T2R 10 is expressed in human PDAC tissue and human pancreatic cancer cell lines}

T2R10 is expressed in primary human pancreatic tumor tissues. According to the data provided by the HiPO biobank, T2R10 mRNA was found in 63 of 84 tumors $(75 \%)$ (Fig. 1A). For detection of T2R10 on protein level, a second cohort of 62 tissue samples from patients with pancreatic ductal adenocarcinoma was analyzed by immunohistochemistry (data of patients summarized in table 1). Here, $79 \%$ of the tumors expressed T2R10. Low expression was seen in $11.3 \%$ of the patients, medium expression in $45.2 \%$, and high expression in $22.6 \%$ (examples in Fig. 1B; data summarized in Fig. 1C). T2R10 was located on the cell surface and in the cytoplasm as well. T2R10 expression did not correlate to pathological parameters including TNM stage, histopathological grading, and R-status. There was, however, a trend towards higher survival rate in patients with high T2R10 expression (Fig. 1D). Moderate to severe intratumor inflammation was seen in the majority of patients, as was infiltration of T cells (example in Fig. 1E). T2R10 expression did not correlate with severity 
nor activity of inflammation, although there might be a trend towards reduced expression of T2R10 in specimen with high inflammatory activity (Fig. 1F). Normal pancreatic tissue reveals single cellular weak T2R10 staining in acinar cells and ductal epithelial cells. Eight human pancreatic cancer cell lines, Aspc-1, BxPC-3, Capan-1, COLO-357, Miapaca-2, PANC-1, Su.86.86, and T3M4 were tested for expression of T2R10 by mRNA by reverse transcription polymerase chain reaction. All cell lines showed T2R10 transcripts (Fig. 2A). For further studies two of these cell lines, BxPC-3, expressing high T2R10, and PANC-1 with low T2R10 (Fig. 2B and 2C) were selected. BxPC-3 and PANC-1 differed with regard to their sensitivity

A

$784 \mathrm{bp}$

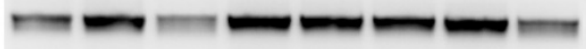

$\mathrm{T} 2 \mathrm{R} 10$

$287 \mathrm{bp}$

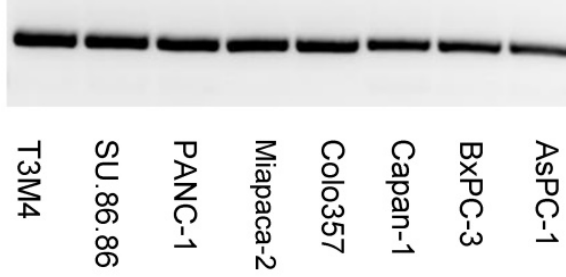

B

BXPC-3 PANC-1

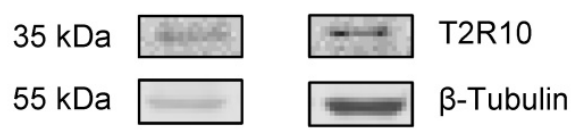

C
BxPC-3

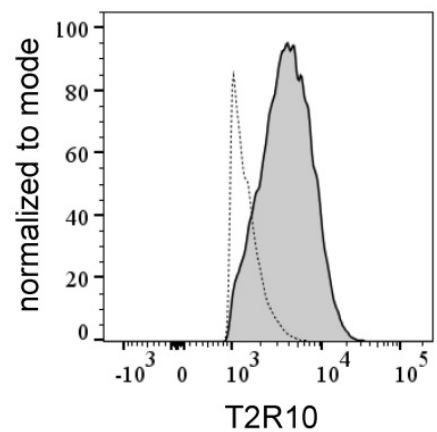

PANC-1

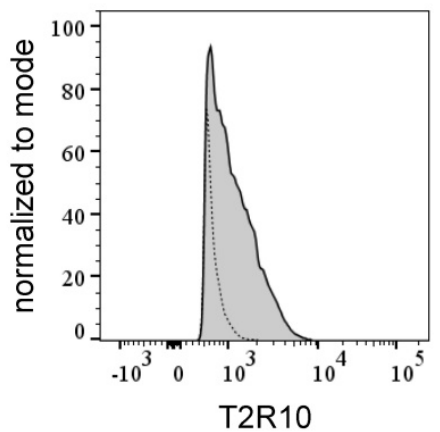

Figure 2: T2R10 expression in tumor derived cell lines. A Agarose gel electrophoresis analysis of PCR products. T2R10 mRNA was determined in eight pancreatic tumor cell lines. B T2R 10 expression was assessed by Western blotting the cell lines BxPC3 and PANC-1 C Flow cytometry analysis was used to detect T2R10 surface expression in BxPC-3 and PANC-1 cell lines (bold line indicates binding of anti-T2R10, dotted line is IgG isotype control). towards chemotherapy, with PANC-1 being more resistant [39], and in our hands a 100-times higher concentration of Gemcitabine was required to cause cell death in ranges similar to BxPC3.

\section{Caffeine increases Gemcitabine or 5-FU-induced cell death}

To test for T2R10-mediated effects on the chemoresponse of BxPC-3 and PANC-1, caffeine, a known and widely used T2R10 agonist [12], was used, and sensitivity of the tumor cells towards either Gemcitabine or 5-FU was tested (protocol in supplementary Fig. 1A). Caffeine alone reduced the viability of the cells slightly. Hundred $\mu \mathrm{M}$ caffeine, however, enhanced the 5-FU-induced cell death by $17 \%(\mathrm{p}<0.05)$ in BxPC-3 (Figs. $3 \mathrm{~A}, \mathrm{~B})$, and the Gemcitabine-induced cell death by $14 \%(p<0.01)$ in PANC-1 cells (Figs. 3C,D). When $200 \mu \mathrm{M}$ caffeine was added to BxPC-3, cell viability in the combinational treatment subset was reduced by $46 \%$ as compared to Gemcitabine alone $(\mathrm{p}<0.01)$ and $25 \%$ $(\mathrm{p}<0.01)$ compared to 5-FU alone (Figs. 3 A,B). Similarly, in PANC-1, cells treated with Gemcitabine and $200 \mu \mathrm{M}$ caffeine or 5-FU and $200 \mu \mathrm{M}$ caffeine showed a significant decrease in cell viability $(34 \%$ for Gemcitabine; $p<0.001$ ) and $31 \%$ for 5-FU ( $p<0.001)$ (Figs. 3C,D), when compared to cells exposed to chemotherapeutic treatment only.

To test whether the caffeine mediated-effect was dependent on T2R10, the receptor was knocked-down by transient transfection with siRNA. As measured by flow cytometry, protein expression was reduced on average by $85 \%$ in BxPC-3 cells, and $80 \%$ in PANC-1 cells when compared to cells treated with scrambled siRNA (mean of three experiments; Figs. 4A-D). Reduced expression of T2R10 could be confirmed by Western blotting (Fig. 4E).

Cells were then treated with either Gemcitabine or 5-FU at various concentrations, and caffeine $(200 \mu \mathrm{M})$ or PBS (control) (supplementary Fig. 1). In BxPC-3 cells, the treatment with $200 \mu \mathrm{M}$ caffeine reduced the $\mathrm{IC}_{50}$ of Gemcitabine and 5 -FU by $77 \%(\mathrm{p}<0.05)$ and $53 \%(\mathrm{p}<$ 0.01 ), respectively (Figs. 5A,B), but in T2R10 knock-downs only by $37 \%$, suggesting that the caffeine effect was at least in part mediated by T2R10. As 
shown before, PANC-1 cells became more susceptible to either Gemcitabine $(63 \%$; $p<0.01)$ or 5 -FU $(37 \%$; $p$ $<0.01$ ) (Fig. 5C,D). Silencing T2R10, however, had no apparent effect. For both cell lines BxPC-3 and PANC-1, a synergistic effect of caffeine was detected (Table 3 and 4).

\section{Caffeine treatment inhibits Akt phosphorylation at Ser473}

T2R10 agonists such as chloroquine and quinine have been shown to inhibit Akt phosphorylation [40]. Because activation of Akt plays a crucial role in the chemoresponse of pancreatic tumor cells [41-43], we tested whether caffeine reduced Akt-phosphorylation in BxPC-3 and PANC-1 cells. By Western blotting, the ratio of phosphorylated (activated) Akt to total Akt was determined. In both, BxPC-3 and PANC-1,

A

BXPC-3

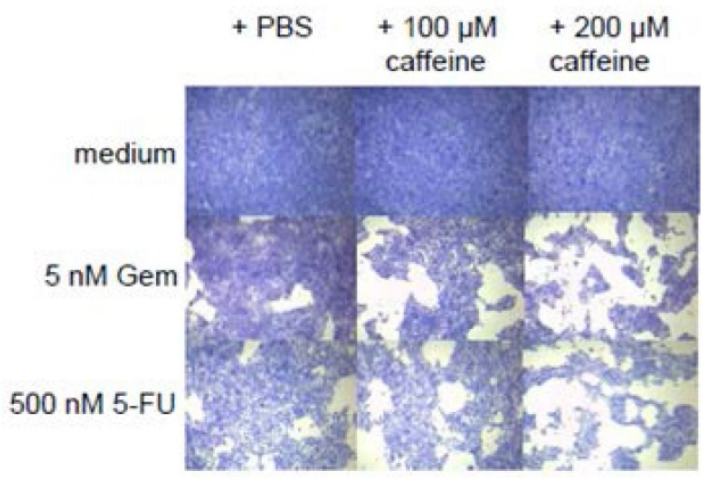

C

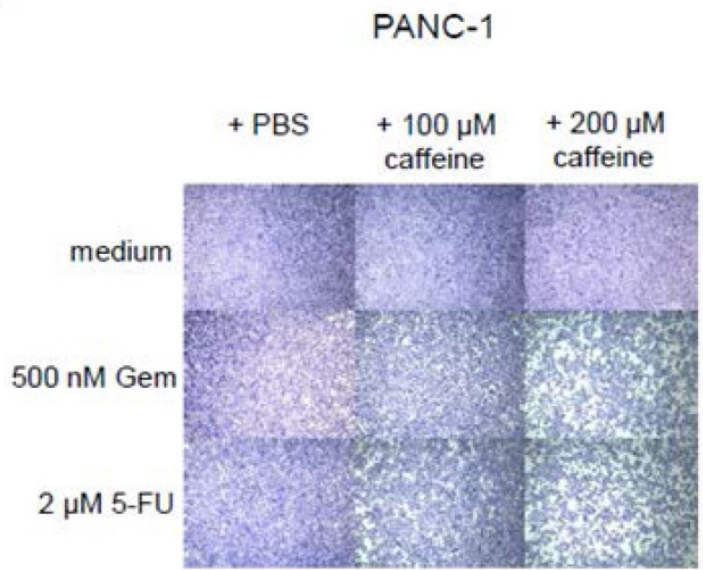

caffeine significantly suppressed the phosphorylation of Akt compared to the control group (PBS) on average of $77 \%$ and $70 \%$ respectively (Figs. $6 \mathrm{~A}, \mathrm{~B}$ and $6 \mathrm{E}, \mathrm{F})$. Silencing of T2R10 prevented the caffeinemediated inhibition of Akt phosphorylation in BxPC-3 (Figs. 6C,D), whereas for PANC-1 still an effect, though somewhat reduced was seen (Figs. $6 \mathrm{G}, \mathrm{H})$.

\section{Caffeine downregulates ABCG2 protein expression}

One of the downstream targets of Akt is ABCG2 [44, 45], which is crucially involved in multidrug resistance [46-49]. Following exposure to caffeine, ABCG2 protein expression was reduced in both cell lines (data summarized in Fig. 7). Again, silencing of T2R10 abrogated the effect of caffeine.

B

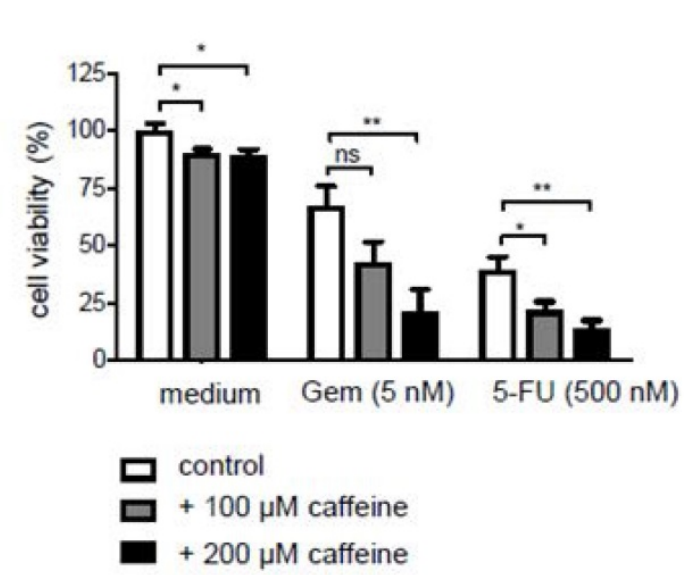

D

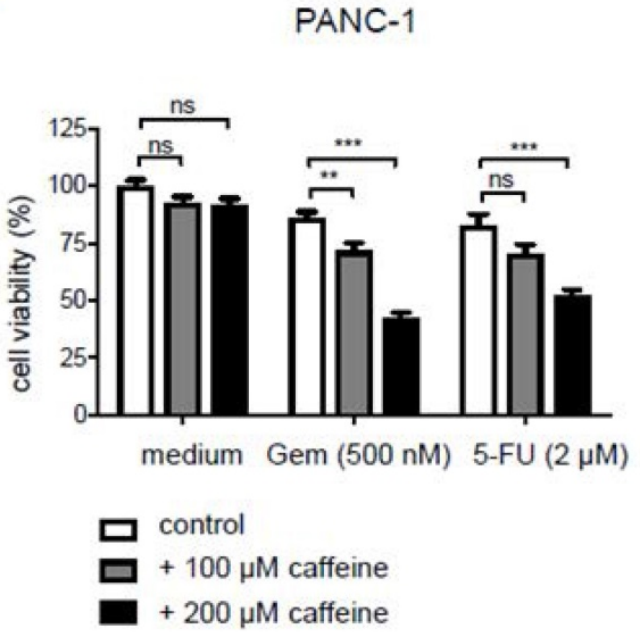

Figure 3: Caffeine increases chemo-responsiveness in pancreatic tumor cells. A Crystal violet staining of BxPC3 exposed to either PBS, caffeine, gemcitabine (Gem), 5-Fluorouracil (5-FU), or combined treatment. B shows the quantification of these data (open bar: PBS; grey bar $100 \mu M$ caffeine; black bar 200 $\mu \mathrm{M}$ caffeine). C,D show the same experimental set up for PANC-1. (Values were normalized to the control group treated with PBS. Data are presented as mean $+/-$ SEM of three independent experiments, each performed in triplicates. Statistical significance was assessed with one-way Anova analysis followed by Dunnett post-hoc test. $\left(*_{\mathrm{p}}<0.05, * * \mathrm{p}<0.01, * * * \mathrm{p}<0.001\right)$ 


\section{Discussion}

Despite an increasing understanding of the molecular mechanisms underlying pancreatic cancer, the therapeutic options are still limited. Hence, also unconventional or unattended targets come into the focus of research, among those bitter-tasting food compounds, such as bitter melon extract, epigallocatechin-3-gallate, or caffeine, which have some anticancer activities [28-32]. All these substances act through specialized bitter receptors, and enhance the chemotoxicity of anticancer drugs, whereby the exact
A

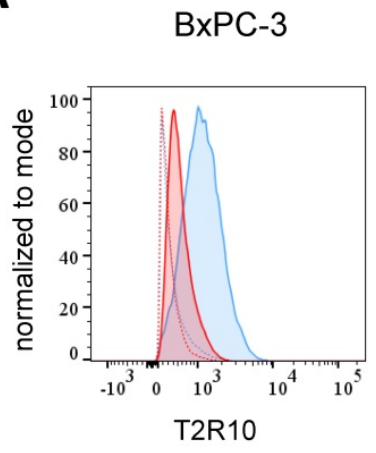

C

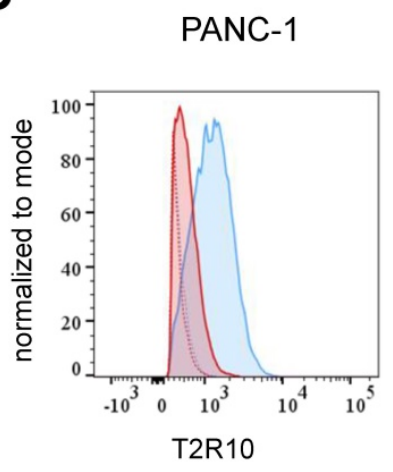

B

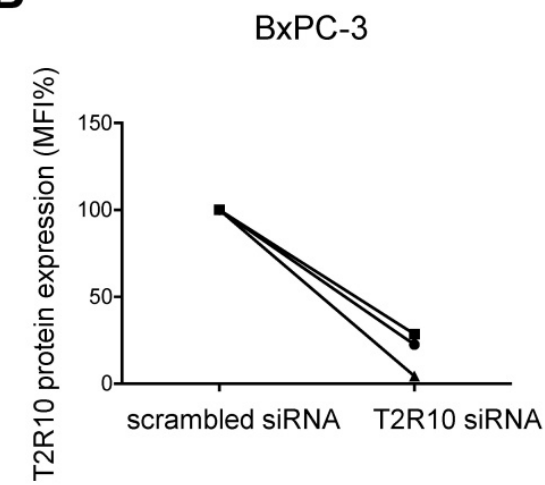

D

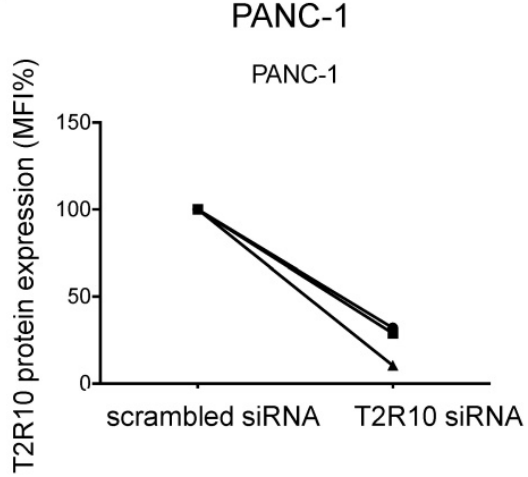

E

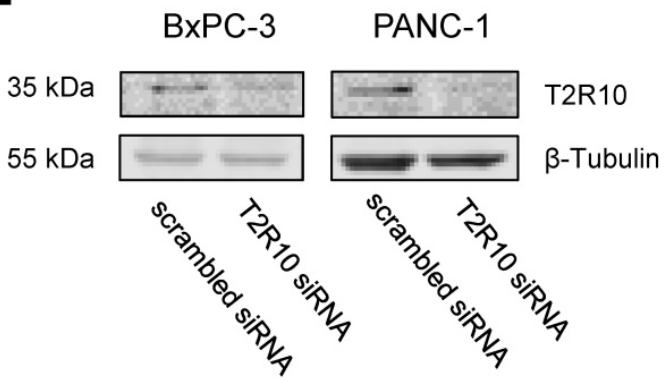

Figure 4: siRNA knockdown of T2R10. Flow cytometry analysis was used to determine surface expression of T2R10 in BxPC-3 (A) and PANC-1 cells (C) transfected with either scrambled siRNA (blue line) or siRNA targeted against T2R10 (red line). Thick lines represent antibody binding to T2R 10 and dotted lines isotype control. B,D Quantification of the mean fluorescence intensity (MFI) indicates a reduction of T2R 10 expression in BxPC-3 and PANC-1 (three independent experiments are shown; MFI for cells treated with scrambled siRNA was set as $100 \%$ ). E Western blot analysis confirmed silencing of T2R 10 on protein level molecular mechanisms have not been fully elucidated as yet [28-32]. Because chemoresistance to numerous chemotherapeutics is a major problem in the therapy of pancreatic cancer [3, 4], we addressed the question whether pancreatic cancer cells expressed a functional bitter receptor for caffeine, and whether signaling via this receptor would affect chemoresistance of a given tumor cell. Caffeine was chosen, because epidemiologic data suggested a protective effect, e.g. for liver cancer [50].

We found expression of T2R10 in the majority of human pancreatic cancer samples $(79 \%)$, whereas T2R10 was basically not detected in normal pancreatic tissue. Expression varied among patients. Although survival of patients with tumors with high T2R10 expression was prolonged, there was no correlation to clinical data. A trend towards lower expression of T2R10 was seen in patients with high inflammatory score, which would be in line with the observation that a high intratumor inflammatory reaction is associated with reduced survival in PDAC [51]. Whether there is a direct link between inflammation and T2R10 expression cannot be decided as yet, because there is, so far, no evidence for regulation of T2R10 expression by inflammatory mediators.

To assess a possible function of T2R10, pancreatic cancer cell lines were used. All cell lines tested expressed T2R10, though to a varying degree. Of these, two cell lines were chosen, namely BxPC3, which showed high surface expression of T2R10, and PANC-1, which according to our flow cytometry data expressed little T2R10. These cell lines also differ with regard to their susceptibility towards the used chemotherapeutics, still for both a pronounced effect of caffeine was seen, and caffeine and the chemotherapeutics act in a synergistic manner (see tables 3 and 4). To assess the participation of T2R10, receptor expression was silenced by siRNA. On average, there was a $70 \%$ downregulation of surface expression. In BxPC-3 cells, silencing of T2R10 reduced the caffeine-induced effect, indicative of a participation of T2R10. In PANC-1, silencing of T2R10 had no substantial effect, suggesting an alternative caffeine signaling pathway. 
A

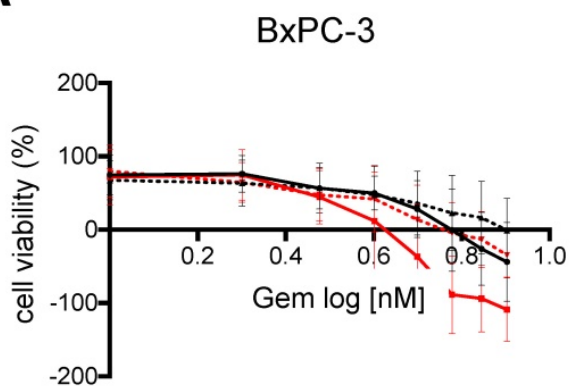

B

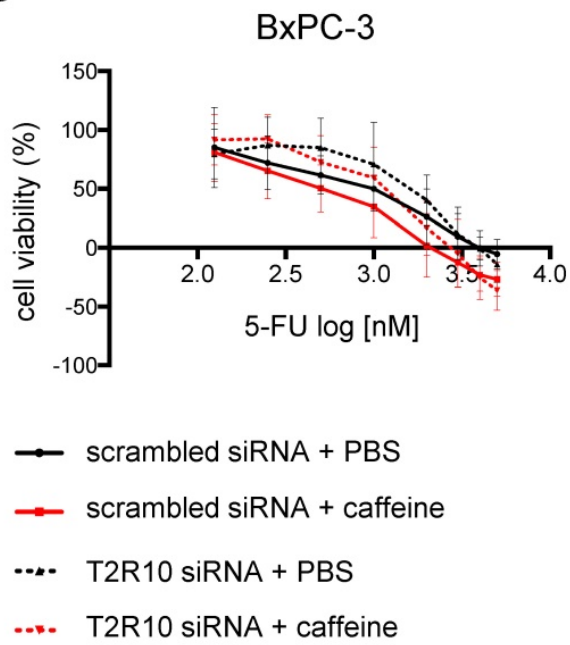

C

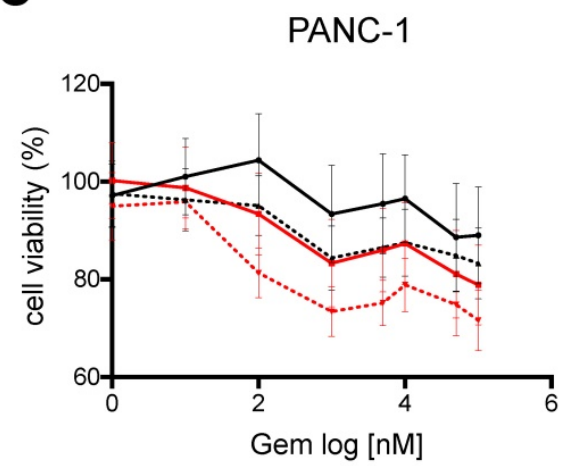

D

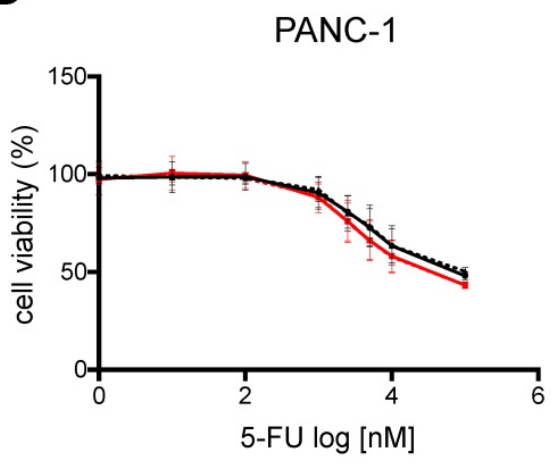

Figure 5: Combined treatment with caffeine reduces IC $_{50}$ of Gemcitabine and 5-FU. BxPC-3 (left panel) and PANC-1 (right panel) were treated with various concentrations of Gemcitabine (upper panel) or 5-FU (lower panel), with or without caffeine (200 $\mu$ M). Compared are cells silenced for T2R10 expression with those transfected with scrambled siRNA. MTS assay was used to determine the number of viable cells after treatment. Values were normalized to the groups treated neither with Gemcitabine nor 5-FU. Each data point represents the mean +/- SEM of at least three independent experiments, each of them performed in triplicates.

Table 2. Effect of caffeine on Gemcitabine and 5-FU-induced cytotoxicity

\begin{tabular}{|c|c|c|c|c|c|c|}
\hline & \multicolumn{3}{|l|}{$\mathrm{IC}_{50}{ }^{*}(\mathrm{nM})$} & \multicolumn{3}{|c|}{$\mathrm{IC}_{50}(\mathrm{nM})$} \\
\hline & Gemcitabine & Gemcitabine + caffeine & decrease in $\%$ & 5-FU & 5-FU + caffeine & decrease in $\%$ \\
\hline BxPC-3 scrambled siRNA & 1.7 & 0.4 & $77 \% *$ & 639 & 337 & $53 \% * *$ \\
\hline BxPC-3 T2R10 siRNA & 2.4 & 1.5 & $38 \%$ & 1024 & 641 & $37 \%$ \\
\hline PANC-1 scrambled siRNA & 344,205 & 127,747 & $63 \%$ ** & 6264 & 3922 & $37 \%$ ** \\
\hline PANC-1 T2R10 siRNA & 183,289 & 55,561 & $70 \%{ }^{\star \star \star *}$ & 5918 & 3910 & $34 \%$ ** \\
\hline
\end{tabular}

*IC50 was calculated on the basis of MTS-derived data (mean of three independent experiment). Compared were cells treated with Gemcitabine alone or Gemcitabine plus caffeine; or 5-FU or 5-FU plus caffeine, respectively. As statistical method the extra sum of squares test was used $\left({ }^{*} \mathrm{p}<0.05 ;{ }^{* *} \mathrm{p}<0.01 ;{ }^{* * *} \mathrm{p}<0.001\right)$.

A known downstream target of T2R10 is Akt [40] that regulates numerous cell functions, including cell survival, proliferation and metabolism (reviewed in [52-55]). In our experiments, caffeine reduced the abundance of activated Akt, and subsequently, the expression of its downstream target ABCG2, in BxPC3 in a T2R10-dependent manner; in PANC-1 the caffeine effect was at least in part independent of T2R10. ABCG2 is a transmembrane drug-efflux pump that transports toxic xenobiotic substances out of cells thereby making them less susceptible to drugs (reviewed in [46-49]). Effects of bitter substances such as bitter melon extract and xanthines on ABCG2 have been described before $[28,30]$, as have its effects on chemoresistance to both Gemcitabine and 5-FU in pancreatic tumor cells (MiaPaCa2, ASPC-1) [56]. Furthermore, high ABCG2 expression correlates with poor chemoresponse, and low overall survival in PDAC patients [57, 58]. The experiments with silenced T2R10 indicated that it participates in signaling pathways regulating chemoresistance of pancreatic tumor cells. 
A

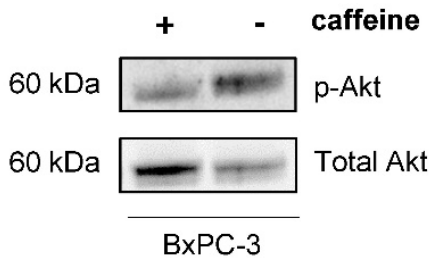

C

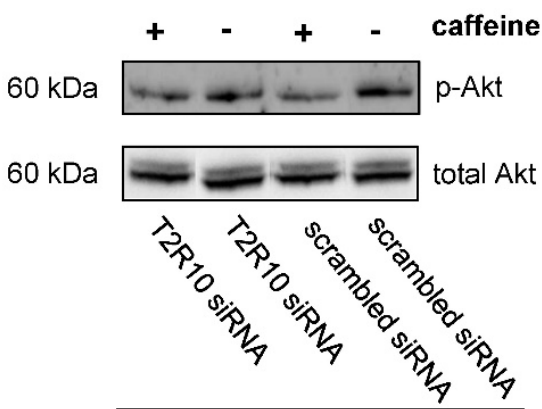

BxPC-3

E

$60 \mathrm{kDa}$

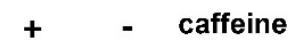

(a)

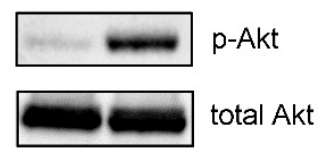

PANC-1

G

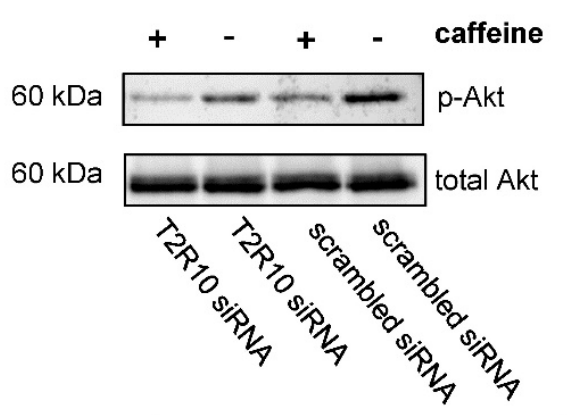

PANC-1
B

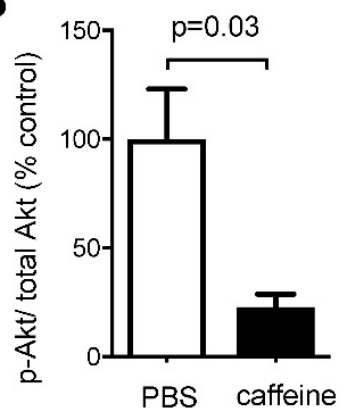

D

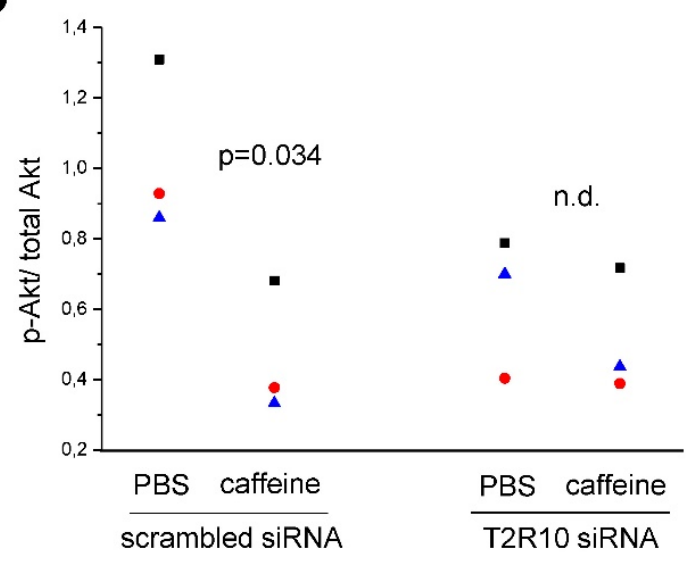

$\mathbf{F}$

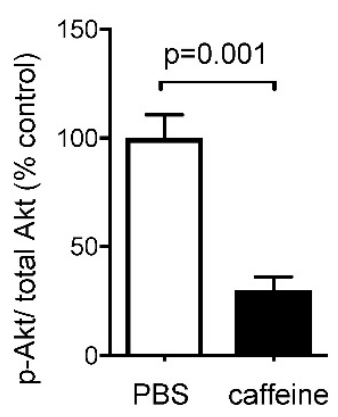

H

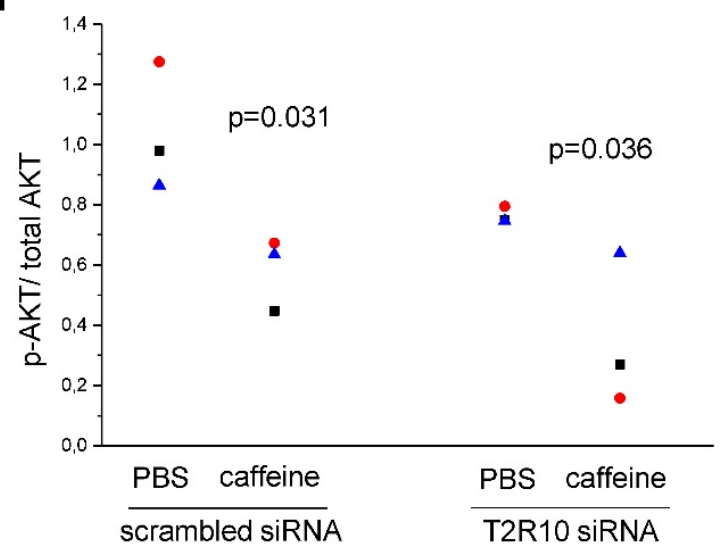

Figure 6: Caffeine inhibits Akt-phosphorylation. BxPC-3 (upper panel) and PANC-1 (lower panel) cells were grown in the presence of serum for 96 hours or for 108 hours in the case of siRNA transfected cells. During this incubation period, five doses of $200 \mu \mathrm{M}$ caffeine were accumulatively added to the medium according to the scheme shown in supplementary Fig. IA and 1C. Akt activation was measured as ratio between phosphorylated Akt (pAkt) and total Akt. A and $\mathbf{E}$ show Western blots and $\mathbf{B}$ and $\mathbf{F}$ the respective quantification (summary of three experiments). $\mathbf{C}$ and $\mathbf{G}$ show Western blots of cells silenced for expression of T2R 10 (T2R10 siRNA) or for comparison cells treated with scrambled siRNA, all cultivated either in the presence of absence of caffeine. D and $\mathbf{H}$ show the respective quantification data (summary of three experiments as indicated by the different symbols (statistical differences between the groups were calculated by ANOVA). 
A

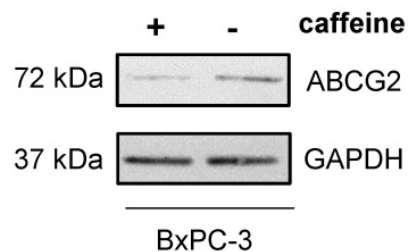

C

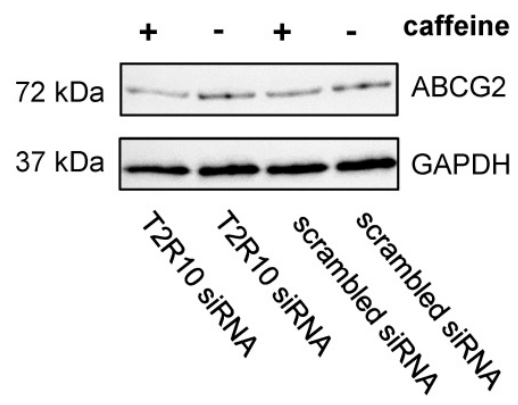

BxPC-3

E

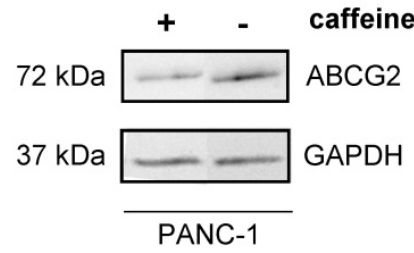

G

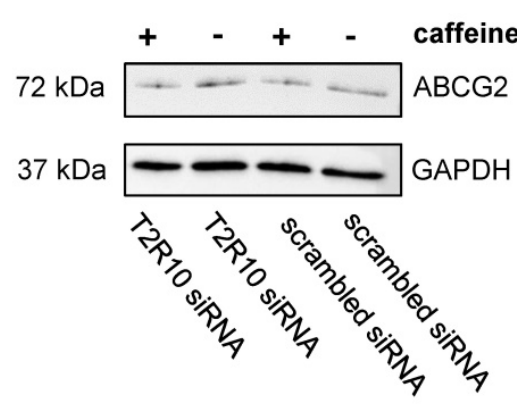

PANC-1
B

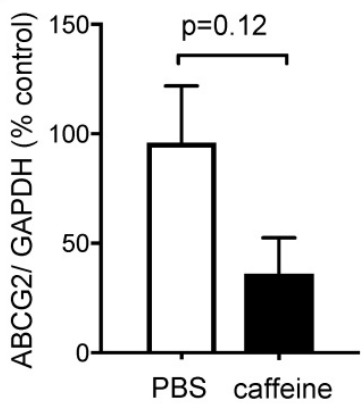

D

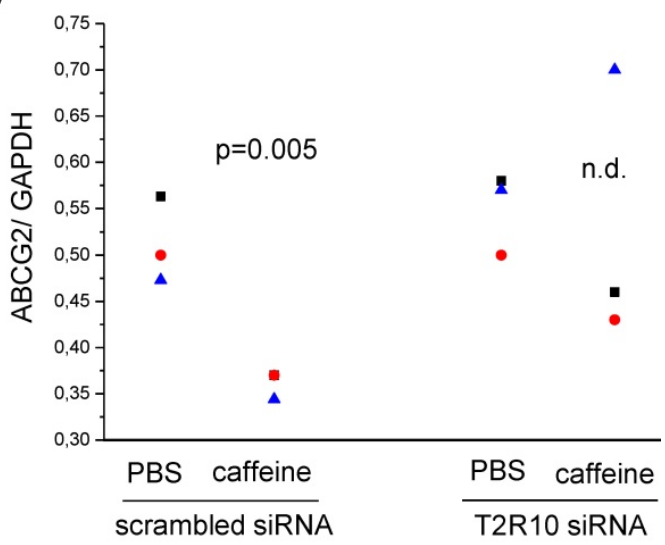

$\mathbf{F}$

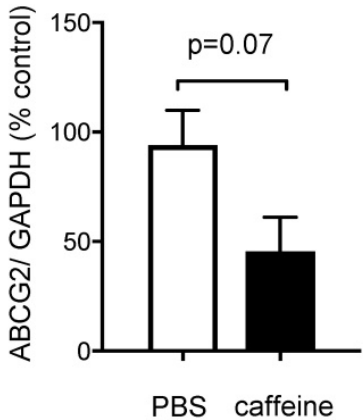

H

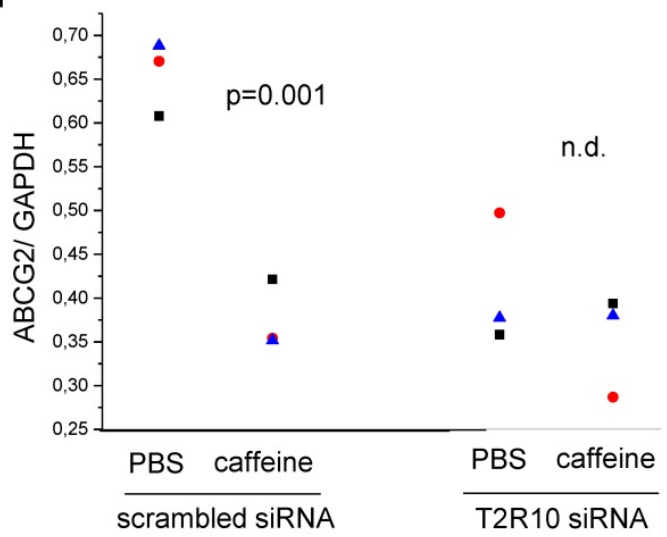

Figure 7: Caffeine down-regulates ABCG2 on protein expression. BxPC-3 (upper panel) and PANC-1 (lower panel) were grown in the presence of serum for 96 hours or 108 hours in the case of siRNA transfected cells. During this incubation period, five doses of $200 \mu M$ caffeine were accumulatively added to the medium according to the scheme shown in supplementary Fig. 1A and 1C. Expression of ABCG2 was measured by Western blotting (A,E) and quantified as ratio of ABCG2 to GAPDH (B,F; summary of three experiments). C, G show cells silenced for expression of T2R10 (T2R10 siRNA) and for comparison cells treated with scrambled siRNA cultivated with or without caffeine. D,E Data from three independent Western blots are shown (groups were compared using ANOVA). 
Table 3. Synergistic effect of caffeine and gemcitabine or 5-FU-induced cytotoxicity in BxPC-3 cells

\begin{tabular}{llllll}
\hline & CDI value & & & & CDI value \\
\cline { 2 - 3 } $\begin{array}{l}\text { Gem } \\
(\mathbf{n M})\end{array}$ & $\begin{array}{l}\text { scrambled } \\
\text { siRNA }\end{array}$ & $\begin{array}{l}\text { T2R10 } \\
\text { siRNA }\end{array}$ & $\begin{array}{l}\mathbf{5 - F U} \\
(\mathbf{n M})\end{array}$ & $\begin{array}{l}\text { scrambled } \\
\text { siRNA }\end{array}$ & $\begin{array}{l}\text { T2R10 } \\
\text { siRNA }\end{array}$ \\
\hline $\mathbf{1}$ & 0.95 & 1.02 & $\mathbf{1 2 5}$ & 0.93 & 1.03 \\
$\mathbf{2}$ & 0.95 & 0.97 & $\mathbf{2 5 0}$ & 0.93 & 1.00 \\
$\mathbf{3}$ & 0.93 & 0.92 & $\mathbf{5 0 0}$ & 0.91 & 0.94 \\
$\mathbf{4}$ & 0.85 & 0.94 & $\mathbf{1 0 0 0}$ & 0.89 & 0.94 \\
$\mathbf{5}$ & 0.76 & 0.85 & $\mathbf{2 0 0 0}$ & 0.85 & 0.90 \\
$\mathbf{6}$ & 0.66 & 0.82 & $\mathbf{3 0 0 0}$ & 0.86 & 0.92 \\
$\mathbf{7}$ & 0.73 & 0.79 & $\mathbf{4 0 0 0}$ & 0.86 & 0.88 \\
$\mathbf{8}$ & 0.73 & 0.75 & $\mathbf{5 0 0 0}$ & 0.87 & 0.89 \\
\hline
\end{tabular}

Table 4. Synergistic effect of caffeine and gemcitabine or 5 -FU-induced cytotoxicity in PANC-1 cells

\begin{tabular}{llllll}
\hline & \multicolumn{2}{l}{ CDI value } & & & \multicolumn{2}{l}{ CDI value } \\
\cline { 2 - 3 } \cline { 5 - 6 } $\begin{array}{l}\text { Gem } \\
(\mathbf{n M})\end{array}$ & $\begin{array}{l}\text { scrambled } \\
\text { siRNA }\end{array}$ & $\begin{array}{l}\text { T2R10 } \\
\text { siRNA }\end{array}$ & $\begin{array}{l}\mathbf{5 - F U} \\
\mathbf{( n M )}\end{array}$ & $\begin{array}{l}\text { scrambled } \\
\text { siRNA }\end{array}$ & $\begin{array}{l}\text { T2R10 } \\
\text { siRNA }\end{array}$ \\
\hline $\mathbf{1}$ & 1.09 & 1.00 & $\mathbf{1}$ & 1.02 & 1.04 \\
$\mathbf{1 0}$ & 1.03 & 1.02 & $\mathbf{1 0}$ & 1.04 & 1.07 \\
$\mathbf{1 0 0}$ & 0.94 & 0.88 & $\mathbf{1 0 0}$ & 1.03 & 1.05 \\
$\mathbf{1 0 0 0}$ & 0.94 & 0.90 & $\mathbf{1 0 0 0}$ & 1.00 & 1.02 \\
$\mathbf{5 0 0 0}$ & 0.95 & 0.89 & $\mathbf{2 5 0 0}$ & 0.96 & 1.00 \\
$\mathbf{1 0 0 0 0}$ & 0.95 & 0.93 & $\mathbf{5 0 0 0}$ & 0.93 & 0.95 \\
$\mathbf{5 0 0 0 0}$ & 0.96 & 0.91 & $\mathbf{1 0 0 0 0}$ & 0.94 & 0.96 \\
$\mathbf{1 0 0 0 0 0}$ & 0.93 & 0.88 & $\mathbf{1 0 0 0 0 0}$ & 0.92 & 0.91 \\
\hline
\end{tabular}

The fact that in PANC-1 caffeine-induced effects were also seen in cells with reduced T2R10 expression suggested involvement of other receptors or alternative triggering mechanisms of caffeine. Possibly, caffeine does not exclusively act through T2R10, but uses also other bitter receptors. It is quite common that bitter tasting substances engage with more than one receptor, and the receptors are promiscuous as well. For caffeine, interactions with T2R7, T2R43, and T2R46 on other cells have been described [12]. Our own, not yet published data, showed expression of T2R43 and T2R46 in PDAC, supporting the notion of multiple receptor engagement. Though not tested rigorously, PANC-1 expressed less T2R10 than BxPC-3, suggesting that receptors other than T2Rs mediated the caffeine effect. On the other hand, also direct effects of caffeine are possible, because among others, it acts as a non-selective inhibitor of phosphodiesterases [59, 60], which leads to increasing levels of intracellular cyclic adenosine nucleotide monophosphate (cAMP) [61], a key second messenger involved in regulation of cellular growth in pancreatic cancer cells [62-64]. Moreover, amphiphilic bitter substances, such as caffeine, in high doses stimulate G-proteins directly, in addition to its activation via the G-protein-linked T2R receptors [65]. Since mechanisms of chemoresistance are usually multifactorial, the observed increase in drug susceptibility could be the result of a summation of several different pathways affected by caffeine.

In conclusion, we have shown for the first time expression of the bitter receptor T2R10 in PDAC, and its involvement in signaling pathways relevant to chemoresistance. Our data support the concept that triggering bitter receptor T2R10 on pancreatic tumor cells is a means to overcome chemoresistance.

\section{Supplementary Material}

Supplementary figure 1.

http://www.jcancer.org/v09p0711s1.pdf

\section{Acknowledgements}

We thank the DKFZ-Heidelberg Center for Personalized Oncology (DKFZ-HIPO) for technical support and funding through HiPO015. We thank Karin Rebholz, Kathrin Schneider, Melanie Heiss, and Markus Herbst for excellent technical support. The work of MMG was funded by the German Research Foundation (DFG; GA 1818/ 2-1).

Pancreatic tissue samples were obtained from the Pancobank of the European Pancreas Center, Department of Surgery, University Hospital Heidelberg or the tissue bank of the National Center for Tumor Diseases (NCT, Heidelberg, Germany) in accordance with the regulations of the tissue bank.

\section{Author Contributions}

L.S. designed and performed the majority of experiments and analyzed data. N.G. performed experiments and analyzed data. T.H. and O.S. collected tissue samples and clinical data and helped with data analysis. P.S. and K.F. analyzed data and helped preparing the manuscript. M.M.G. designed the study, supervised the experiments, analyzed data, and wrote the manuscript. All authors read the manuscript and contributed their suggestions.

\section{Competing Interests}

The authors have declared that no competing interest exists.

\section{References}

1. Siegel RL, Miller KD, Jemal A. Cancer statistics, 2015. CA: a cancer journal for clinicians. 2015; 65: 5-29.

2. Spadi R, Brusa F, Ponzetti A, Chiappino I, Birocco N, Ciuffreda L, et al. Current therapeutic strategies for advanced pancreatic cancer: A review for clinicians. World J Clin Oncol. 2016; 7: 27-43.

3. Chand S, O'Hayer K, Blanco FF, Winter JM, Brody JR. The Landscape of Pancreatic Cancer Therapeutic Resistance Mechanisms. International journal of biological sciences. 2016; 12: 273-82.

4. Di Marco M, Di Cicilia R, Macchini M, Nobili E, Vecchiarelli S, Brandi G, et al. Metastatic pancreatic cancer: is gemcitabine still the best standard treatment? (Review). Oncology reports. 2010; 23: 1183-92.

5. Harikumar KB, Kunnumakkara AB, Sethi G, Diagaradjane P, Anand P, Pandey MK, et al. Resveratrol, a multitargeted agent, can enhance antitumor activity of gemcitabine in vitro and in orthotopic mouse model of human pancreatic cancer. International journal of cancer Journal international du cancer. 2010; 127: 257-68. 
6. Banerjee S, Kaseb AO, Wang Z, Kong D, Mohammad M, Padhye S, et al. Antitumor activity of gemcitabine and oxaliplatin is augmented by thymoquinone in pancreatic cancer. Cancer research. 2009; 69: 5575-83.

7. Banerjee S, Wang Z, Kong D, Sarkar FH. 3,3'-Diindolylmethane enhances chemosensitivity of multiple chemotherapeutic agents in pancreatic cancer. Cancer research. 2009; 69: 5592-600.

8. Zhang JG, Zhao G, Qin Q, Wang B, Liu L, Liu Y, et al. Nicotinamide prohibits proliferation and enhances chemosensitivity of pancreatic cancer cells through deregulating SIRT1 and Ras/Akt pathways. Pancreatotomy : official journal of the International Association of Pancreatology. 2013; 13: 140-6.

9. El-Rayes BF, Ali S, Ali IF, Philip PA, Abbruzzese J, Sarkar FH. Potentiation of the effect of erlotinib by genistein in pancreatic cancer: the role of Akt and nuclear factor-kappaB. Cancer research. 2006; 66: 10553-9.

10. Adler E, Hoon MA, Mueller KL, Chandrashekar J, Ryba NJ, Zuker CS. A novel family of mammalian taste receptors. Cell. 2000; 100: 693-702.

11. Behrens $\mathrm{M}$, Meyerhof $\mathrm{W}$. Bitter taste receptors and human bitter taste perception. Cellular and molecular life sciences: CMLS. 2006; 63: 1501-9.

12. Meyerhof W, Batram C, Kuhn C, Brockhoff A, Chudoba E, Bufe B, et al. The molecular receptive ranges of human TAS2R bitter taste receptors. Chem Senses. 2010; 35: 157-70.

13. Behrens $M$, Meyerhof W. Bitter taste receptor research comes of age: from characterization to modulation of TAS2Rs. Seminars in cell \& developmental biology. 2013; 24: 215-21.

14. Behrens M, Gunn HC, Ramos PC, Meyerhof W, Wooding SP. Genetic, functional, and phenotypic diversity in TAS2R38-mediated bitter taste perception. Chemical senses. 2013; 38: 475-84.

15. Narukawa M, Noga C, Ueno Y, Sato T, Misaka T, Watanabe T. Evaluation of the bitterness of green tea catechins by a cell-based assay with the human bitter taste receptor hTAS2R39. Biochemical and biophysical research communications. 2011; 405: 620-5

16. Gaida MM, Dapunt U, Hansch GM. Sensing developing biofilms: the bitter receptor T2R38 on myeloid cells. Pathogens and disease. 2016; 74.

17. Shah AS, Ben-Shahar Y, Moninger TO, Kline JN, Welsh MJ. Motile cilia of human airway epithelia are chemosensory. Science (New York, NY). 2009; 325: $1131-4$

18. Singh N, Chakraborty R, Bhullar RP, Chelikani P. Differential expression of bitter taste receptors in non-cancerous breast epithelial and breast cancer cells. Biochemical and biophysical research communications. 2014; 446: 499-503.

19. Latorre R, Huynh J, Mazzoni M, Gupta A, Bonora E, Clavenzani P, et al. Expression of the Bitter Taste Receptor, T2R38, in Enteroendocrine Cells of the Colonic Mucosa of Overweight/Obese vs. Lean Subjects. PloS one. 2016; 11: e0147468.

20. Wolfle U, Elsholz FA, Kersten A, Haarhaus B, Schumacher U, Schempp CM. Expression and Functional Activity of the Human Bitter Taste Receptor TAS2R38 in Human Placental Tissues and JEG-3 Cells. Molecules. 2016; 21.

21. Singh N, Vrontakis M, Parkinson F, Chelikani P. Functional bitter taste receptors are expressed in brain cells. Biochemical and biophysical research communications. 2011; 406: 146-51.

22. Lee RJ, Kofonow JM, Rosen PL, Siebert AP, Chen B, Doghramji L, et al. Bitter and sweet taste receptors regulate human upper respiratory innate immunity. The Journal of clinical investigation. 2014; 124: 1393-405.

23. Manson ML, Safholm J, Al-Ameri M, Bergman P, Orre AC, Sward K, et al. Bitter taste receptor agonists mediate relaxation of human and rodent vascular smooth muscle. European journal of pharmacology. 2014; 740: 302-11.

24. Jing F, Liu M, Yang N, Liu Y, Li X, Li J. Relaxant effect of chloroquine in rat ileum: possible involvement of nitric oxide and BKCa. The Journal of pharmacy and pharmacology. 2013; 65: 847-54.

25. Zhang $\mathrm{CH}$, Lifshitz LM, Uy KF, Ikebe M, Fogarty KE, ZhuGe R. The cellular and molecular basis of bitter tastant-induced bronchodilation. PLoS biology. 2013; 11: e1001501.

26. Tan X, Sanderson MJ. Bitter tasting compounds dilate airways by inhibiting airway smooth muscle calcium oscillations and calcium sensitivity. British journal of pharmacology. 2014; 171: 646-62.

27. Gaida MM, Mayer C, Dapunt U, Stegmaier S, Schirmacher P, Wabnitz GH, et al. Expression of the bitter receptor T2R38 in pancreatic cancer: localization in lipid droplets and activation by a bacteria-derived quorum-sensing molecule. Oncotarget. 2016.

28. Kwatra D, Venugopal A, Standing D, Ponnurangam S, Dhar A, Mitra A, et al. Bitter melon extracts enhance the activity of chemotherapeutic agents through the modulation of multiple drug resistance. Journal of pharmaceutical sciences. 2013; 102: 4444-54

29. Lyn-Cook BD, Rogers T, Yan Y, Blann EB, Kadlubar FF, Hammons GJ. Chemopreventive effects of tea extracts and various components on human pancreatic and prostate tumor cells in vitro. Nutrition and cancer. 1999; 35: 80-6.

30. Ding R, Shi J, Pabon K, Scotto KW. Xanthines down-regulate the drug transporter ABCG2 and reverse multidrug resistance. Molecular pharmacology. 2012; 81: 328-37.

31. Kawano $\mathrm{Y}$, Nagata $\mathrm{M}$, Kohno $\mathrm{T}$, Ichimiya $\mathrm{A}$, Iwakiri $\mathrm{T}$, Okumura $\mathrm{M}$, et al. Caffeine increases the antitumor effect of Cisplatin in human hepatocellular carcinoma cells. Biological \& pharmaceutical bulletin. 2012; 35: 400-7.

32. Mei $Y$, Wei D, Liu J. Reversal of cancer multidrug resistance by tea polyphenol in KB cells. Journal of chemotherapy. 2003; 15: 260-5.

33. Allred DC, Harvey JM, Berardo M, Clark GM. Prognostic and predictive factors in breast cancer by immunohistochemical analysis. Modern pathology: an official journal of the United States and Canadian Academy of Pathology, Inc. 1998; 11: 155-68

34. Gaida MM, Welsch T, Herpel E, Tschaharganeh DF, Fischer L, Schirmacher P, et al. MHC class II expression in pancreatic tumors: a link to intratumoral inflammation. Virchows Arch. 2012; 460: 47-60.

35. Mortazavi A, Williams BA, McCue K, Schaeffer L, Wold B. Mapping and quantifying mammalian transcriptomes by RNA-Seq. Nat Methods. 2008; 5: $621-8$

36. Morgan RT, Woods LK, Moore GE, Quinn LA, McGavran L, Gordon SG. Human cell line (COLO 357) of metastatic pancreatic adenocarcinoma. International journal of cancer Journal international du cancer. 1980; 25: 591-8.

37. Chou TC. Theoretical basis, experimental design, and computerized simulation of synergism and antagonism in drug combination studies. Pharmacol Rev. 2006; 58: 621-81.

38. Thermo Fisher Scientific. User Guide: Pierce BCA Protein Assay Rockford, IL, USA.

39. Kim Y, Han D, Min H, Jin J, Yi EC, Kim Y. Comparative proteomic profiling of pancreatic ductal adenocarcinoma cell lines. Molecules and cells. 2014; 37: 888-98.

40. Sharma P, Panebra A, Pera T, Tiegs BC, Hershfeld A, Kenyon LC, et al. Antimitogenic effect of bitter taste receptor agonists on airway smooth muscle cells. American journal of physiology Lung cellular and molecular physiology. 2016; 310: L365-76.

41. Fahy BN, Schlieman M, Virudachalam S, Bold RJ. AKT inhibition is associated with chemosensitisation in the pancreatic cancer cell line MIA-PaCa-2. British journal of cancer. 2003; 89: 391-7.

42. West KA, Castillo SS, Dennis PA. Activation of the PI3K/Akt pathway and chemotherapeutic resistance. Drug resistance updates: reviews and commentaries in antimicrobial and anticancer chemotherapy. 2002; 5: 234-48.

43. Ng SS, Tsao MS, Nicklee T, Hedley DW. Wortmannin inhibits pkb/akt phosphorylation and promotes gemcitabine antitumor activity in orthotopic human pancreatic cancer xenografts in immunodeficient mice. Clinical cancer research: an official journal of the American Association for Cancer Research. 2001; 7: 3269-75.

44. Huang FF, Zhang L, Wu DS, Yuan XY, Yu YH, Zhao XL, et al. PTEN regulates $\mathrm{BCRP} / \mathrm{ABCG} 2$ and the side population through the PI3K/Akt pathway in chronic myeloid leukemia. PLoS One. 2014; 9: e88298.

45. Bleau AM, Hambardzumyan D, Ozawa T, Fomchenko EI, Huse JT, Brennan $\mathrm{CW}$, et al. PTEN/PI3K/Akt pathway regulates the side population phenotype and ABCG2 activity in glioma tumor stem-like cells. Cell stem cell. 2009; 4: 226-35.

46. Allen JD, Schinkel AH. Multidrug resistance and pharmacological protection mediated by the breast cancer resistance protein (BCRP/ABCG2). Molecular cancer therapeutics. 2002; 1: 427-34

47. Natarajan $\mathrm{K}, \mathrm{Xie} Y$, Baer MR, Ross DD. Role of breast cancer resistance protein (BCRP/ABCG2) in cancer drug resistance. Biochemical pharmacology. 2012; 83: 1084-103.

48. Mo W, Zhang JT. Human ABCG2: structure, function, and its role in multidrug resistance. International journal of biochemistry and molecular biology. 2012; 3: 1-27.

49. Doyle L, Ross DD. Multidrug resistance mediated by the breast cancer resistance protein BCRP (ABCG2). Oncogene. 2003; 22: 7340-58.

50. Setiawan VW, Wilkens LR, Lu SC, Hernandez BY, Le Marchand L, Henderson BE. Association of coffee intake with reduced incidence of liver cancer and death from chronic liver disease in the US multiethnic cohort. Gastroenterology. 2015; 148: 118-25; quiz e15

51. Alam MS, Gaida MM, Bergmann F, Lasitschka F, Giese T, Giese NA, et al. Selective inhibition of the p38 alternative activation pathway in infiltrating $\mathrm{T}$ cells inhibits pancreatic cancer progression. Nature medicine. 2015; 21: 1337-43

52. Mundi PS, Sachdev J, McCourt C, Kalinsky K. AKT in cancer: new molecular insights and advances in drug development. British journal of clinical pharmacology. 2016

53. Vivanco I, Sawyers CL. The phosphatidylinositol 3-Kinase AKT pathway in human cancer. Nat Rev Cancer. 2002; 2: 489-501.

54. Manning BD, Cantley LC. AKT/PKB signaling: navigating downstream. Cell. 2007; 129: 1261-74.

55. Jiang SJ, Hsu SY, Deng CR, Huang HC, Liu SL, Shi GY, et al. Dextromethorphan attenuates LPS-induced adhesion molecule expression in human endothelial cells. Microcirculation. 2013; 20: 190-201.

56. Hamada S, Satoh K, Hirota M, Kanno A, Umino J, Ito H, et al. The homeobox gene MSX2 determines chemosensitivity of pancreatic cancer cells via the regulation of transporter gene ABCG2. J Cell Physiol. 2012; 227: 729-38.

57. Lee SH, Kim H, Hwang JH, Lee HS, Cho JY, Yoon YS, et al. Breast cancer resistance protein expression is associated with early recurrence and decreased survival in resectable pancreatic cancer patients. Pathology international. 2012; 62: 167-75

58. Yuan Y, Yang Z, Miao X, Li D, Liu Z, Zou Q. The clinical significance of FRAT1 and ABCG2 expression in pancreatic ductal adenocarcinoma. Tumour Biol. 2015; 36: 9961-8.

59. Wells JN, Miller JR. Methylxanthine inhibitors of phosphodiesterases. Methods in enzymology. 1988; 159: 489-96.

60. Sawynok J, Yaksh TL. Caffeine as an Analgesic Adjuvant - a Review of Pharmacology and Mechanisms of Action. Pharmacol Rev. 1993; 45: 43-85. 
61. Sutherland EW, Rall TW. Fractionation and Characterization of a Cyclic Adenine Ribonucleotide Formed by Tissue Particles. Journal of Biological Chemistry. 1958; 232: 1077-91.

62. Cho-Chung YS, Pepe S, Clair T, Budillon A, Nesterova M. cAMP-dependent protein kinase: role in normal and malignant growth. Crit Rev Oncol Hematol. 1995; 21: 33-61.

63. Zhao H, Wei R, Wang L, Tian Q, Tao M, Ke J, et al. Activation of glucagon-like peptide-1 receptor inhibits growth and promotes apoptosis of human pancreatic cancer cells in a cAMP-dependent manner. Am J Physiol Endocrinol Metab. 2014; 306: E1431-41.

64. Lorenz R, Aleksic T, Wagner M, Adler G, Weber CK. The cAMP/Epac1/Rap1 pathway in pancreatic carcinoma. Pancreas. 2008; 37: 102-3.

65. Naim M, Seifert R, Nurnberg B, Grunbaum L, Schultz G. Some taste substances are direct activators of G-proteins. The Biochemical journal. 1994; 297 (Pt 3): 451-4. 